\title{
STATISTICAL MODELLING OF THE NUMBER OF INFECTED FRUITING BODIES OF COMMON MUSHROOMS IN CULTIVATION INTEGRATED WITH PREPARATIONS CONTAINING BENEFICIAL MICROORGANISMS
}

\author{
Katarzyna Szwedziak, Ewa Polańczyk ${ }^{*}$ \\ Department of Biosystems Engineering, Opole University of Technology, Poland \\ ${ }^{*}$ Corresponding author: e-mail ewa_polanczyk@op.pl
}

\begin{tabular}{|c|c|}
\hline ARTICLE INFO & ABSTRACT \\
\hline $\begin{array}{l}\text { Article history: } \\
\text { Received: April } 2018 \\
\text { Received in the revised form: } \\
\text { May } 2018 \\
\text { Accepted: June } 2018\end{array}$ & \multirow[t]{2}{*}{$\begin{array}{l}\text { Due to low effectiveness or high costs of using chemical agents in the } \\
\text { protection of common mushrooms, producers are forced to look for } \\
\text { alternative methods of protection. One such method is the use of } \\
\text { preparations containing beneficial microorganisms. A statistical } \\
\text { evaluation of this mushroom protection method and determination of } \\
\text { the number of infected fruiting bodies is presented in this paper. }\end{array}$} \\
\hline $\begin{array}{l}\text { Key words: } \\
\text { common mushroom, } \\
\text { infected fruiting bodies, } \\
\text { statistical evaluation, } \\
\text { beneficial microorganisms }\end{array}$ & \\
\hline
\end{tabular}

\section{Introduction}

Since the dawn of time, mushrooms have been a part of diet for people all over the world. Their taste is particularly appreciated. However, it is sometimes heard that mushrooms have no nutritional value due to the presence of chitin in their cell walls. Nothing could be further from the truth - scientific research has shown that mushrooms, apart from their high nutritional value, also have a proven healing effect (Szudyga, 2008). Since 1957, when Lucas discovered the anticancer properties of mushrooms, it has been proven that eating fresh common mushrooms (Agaricus Bisporus) prevents prostate cancer in men (Adams et al., 2008). After the discovery of many antioxidants in the common mushroom, it started to be referred to as "the superfood" and recommended as food preventing tumours and various heart diseases (Beelman et al., 2003). The nutritional value of the common mushroom is also confirmed by the proven content of the vitamin B complex, phosphorus, magnesium, potassium, and selenium (Mazur, 2004). The low content of sodium, fat and energy as well as the high content of protein make the common mushroom a dietetic and easily digestible food, highly valued among vegetarians (Clark, 2010). For this reason, a continuous increase in the production of the common mushroom is observed both worldwide and in Poland (Wojciechowska-Mazurek et al., 2011).

The production of common mushrooms in Poland is a horticultural department characterised by high growth dynamics. The development of this production is associated with strong production traditions and experience gained over the last half century. It is not without significance that in the centrally planned economy this sector was dominated by the 
private sector (Trajer et al., 2013). The dissemination of technological and technical progress in common mushroom production also contributed to an increase in the competitiveness of domestic production. The development of common mushroom production in Poland was also influenced by the good economic situation, which manifested itself in an increase in demand, especially on foreign markets, as well as relatively lower costs of domestic production (especially labour costs) in comparison to other European countries (Ślusarski et al., 2010). A. Bisporus should be cultivated without the use of plant protection agents, which must not come into direct contact with the mushroom, i.e. food. This means changing the approach from control to prevention. This significantly alters the situation, as the aim of the activities undertaken is to prevent losses caused by diseases. The state of knowledge and production practice, as well as the proposed organisational solutions, allow elimination of the threat almost completely. Integrated mushroom protection requires knowledge in many fields. It concerns both the biology of the mushroom, the substrate and harmful organisms, as well as chemical issues related to the use of chemical protection agents and technical issues regarding the construction of the mushroom growing plant and the use of equipment to perform various protection-related tasks (Staniszweski, 2014). Protection measures are an integral part of the common mushroom cultivation technology. Generally speaking, it can be stated that the task of the producer of raw materials and common mushrooms is to create selective conditions for the mushroom and to protect it against the negative influence of the environment, i.e. objects accompanying the mushroom, people and the external environment. It should be assumed that the better the conditions we create for the growth of the mushroom, limiting the possibility of occurrence of diseases and pests, the smaller the losses of cultivation will be (Tekiela, 2010). This means that losses caused by diseases and pests cannot be avoided if the mushroom is cultivated in the microclimatic conditions that are not suitable for it and if the substrate or cover is inappropriate. Any error in technology, such as the lack of complete overgrowth of the substrate, exposes to losses caused by the settling of competing fungi or soil becoming rotted. Threats accompany each stage of the production of raw materials and mushrooms (Martyniuk, 2011).

One of the methods of integrated mushroom production is the use of preparations containing beneficial microorganisms. The application of such formulas may reduce the incidence of infected fruiting bodies of the common mushroom (Wnag et al., 2011)

\section{Objective and methods}

The aim of the study was to evaluate the influence of preparations containing beneficial microorganisms on the number of infected fruiting bodies of the common mushroom (Ślusarski et al., 2010)

The research was conducted in the years 2014-2016 in a mushroom growing plant located in Opolskie Voivodeship, Poland. The research consisted in creating and formulating, and then applying a new innovative technology of common mushroom production with the use of preparations containing beneficial microorganisms in a fully automated mushroom growing plant. The applied dose selection was chosen by mixing two preparations containing beneficial microorganisms (EmFarma, Ema 5), and increasing the content of each formula in individual doses two and three times in relation to the initial dose. 
Statistical modelling...

Having developed the new innovative technology, 10 complete production cycles were carried out in four cultivation halls at the same time for the target duration of the research study. The traditional production of mushrooms took place in one of the cultivation halls, while the new innovative production technology was applied simultaneously in three other halls, using preparations containing beneficial microorganisms. In three cultivation halls, individual doses of preparations containing beneficial microorganisms were studied (doses were marked A, B, C), and the fourth cultivation hall (marked D) was a control hall where no new integrated technology was applied.

The following doses of the preparations were used in the study: dose A - starting dose with the concentration of $1.6 \%$, dose B - solution with the concentration of $3.3 \%$, dose $\mathrm{C}$ - solution with the concentration of $4.9 \%$. These doses were applied on the day of loading the substrate and cover on shelves and on the $23^{\text {rd }}$ day of the production cycle during the last watering process. Dose D was a control sample where the preparations with beneficial microorganisms were not used. The diagram for the mushroom production technology is presented below, in which the application of the preparations containing beneficial microorganisms is taken into account.

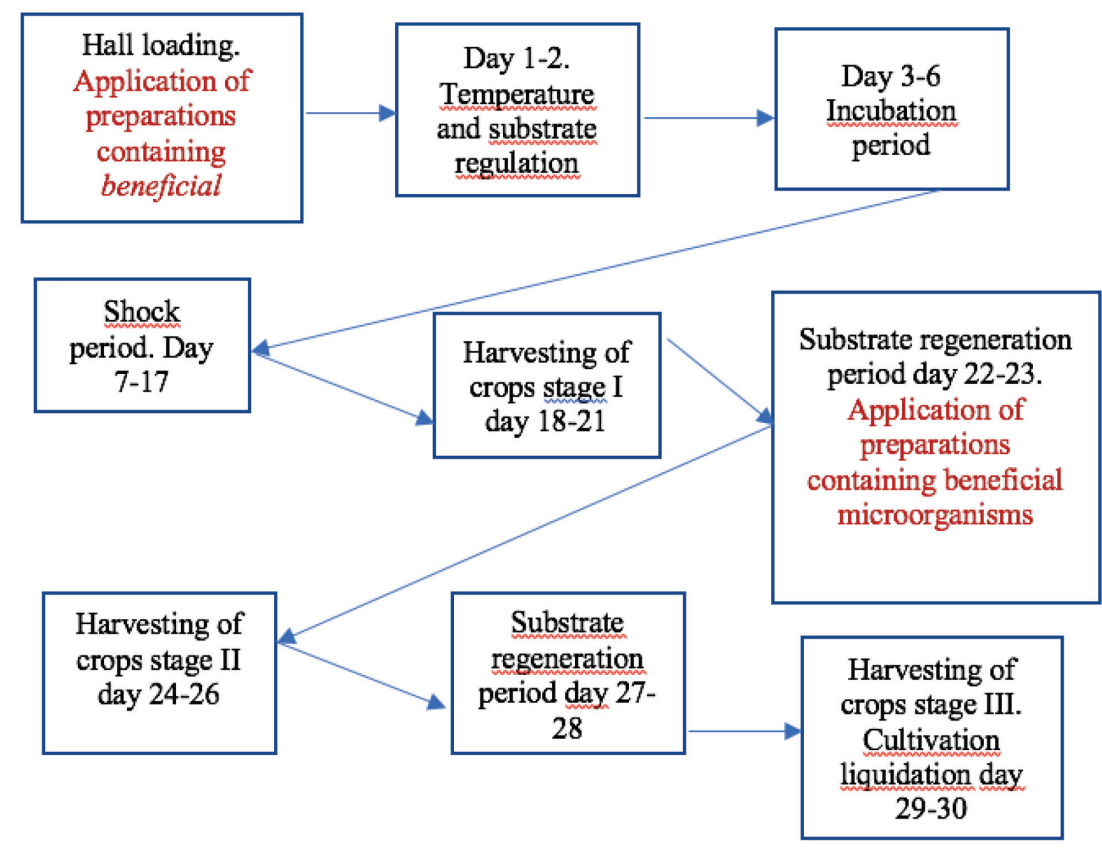

Figure 1. Technological diagram of common mushroom production including application of preparations containing beneficial microorganisms (own elaboration) 
The preparations containing beneficial microorganisms were applied twice - for the first time on the conveyor belt of a combine harvester for loading. Additional elements of the conveyor belt, in the form of a sprinkler system with appropriately selected nozzles, were mounted on the combine harvester. Due to the fact that the pressure in the liquid distribution nozzles may adversely affect application efficiency of the preparations causing damage to the cell structures of the microorganisms, long 0.3 size ejector nozzles were selected and installed, operating at a working pressure of 4 bars. Additionally, the same nozzles were installed on the irrigation system which was used in the second stage of the process of applying the preparations containing beneficial microorganisms in the cultivation of the common mushroom.

\section{Analysis of results and discussion}

The obtained results were subjected to a detailed statistical analysis using the PQStat v.1.6.6 software. Table 1 presents descriptive statistics.

Table 1.

Descriptive statistics of the dependence of doses of the preparation containing beneficial microorganisms on the number of infected fruiting bodies of the cultivated common mushroom.

\begin{tabular}{lcccc}
\hline Descriptive statistics & Dose A & Dose B & Dose C & $\begin{array}{c}\text { Dose D } \\
- \text { control }\end{array}$ \\
\hline Statistical significance & 0.05 & 0.05 & 0.05 & 0.05 \\
Size & 22 & 22 & 22 & 22 \\
Arithmetic mean & 1.20 & 1.46 & 3.51 & 18.23 \\
Median & 0.25 & 0.8 & 1.3 & 5.15 \\
Variance & 3.39 & 7.06 & 20.49 & 671.82 \\
Standard deviation & 1.84 & 2.65 & 4.52 & 25.91 \\
Coefficient of variability & 1.52 & 1.81 & 1.28 & 1.42 \\
Standard error of the mean & 0.39 & 0.56 & 0.96 & 5.52 \\
\hline
\end{tabular}

On the basis of the descriptive statistics obtained, normality tests were carried out for each variant considered.

For the variant where the doses of the preparation were compared to the number of infected fruiting bodies on the basis of the values observed, the results are shown in Figure 2. The following hypotheses were assumed:

$H_{0}$ - distribution differs significantly from normal distribution

$H_{A}$ - distribution is normal

On the basis of the obtained descriptive statistics of the normality test, $H_{0}$ was assumed, which indicates that the distribution of data differs from normal distribution. The obtained statistics $p$ for each variant is in the range of $0.000015-0.00002$. On the basis of the performed analysis, we obtained dependency totalling $p<0.05$, therefore there are grounds to reject $H_{A}$. 

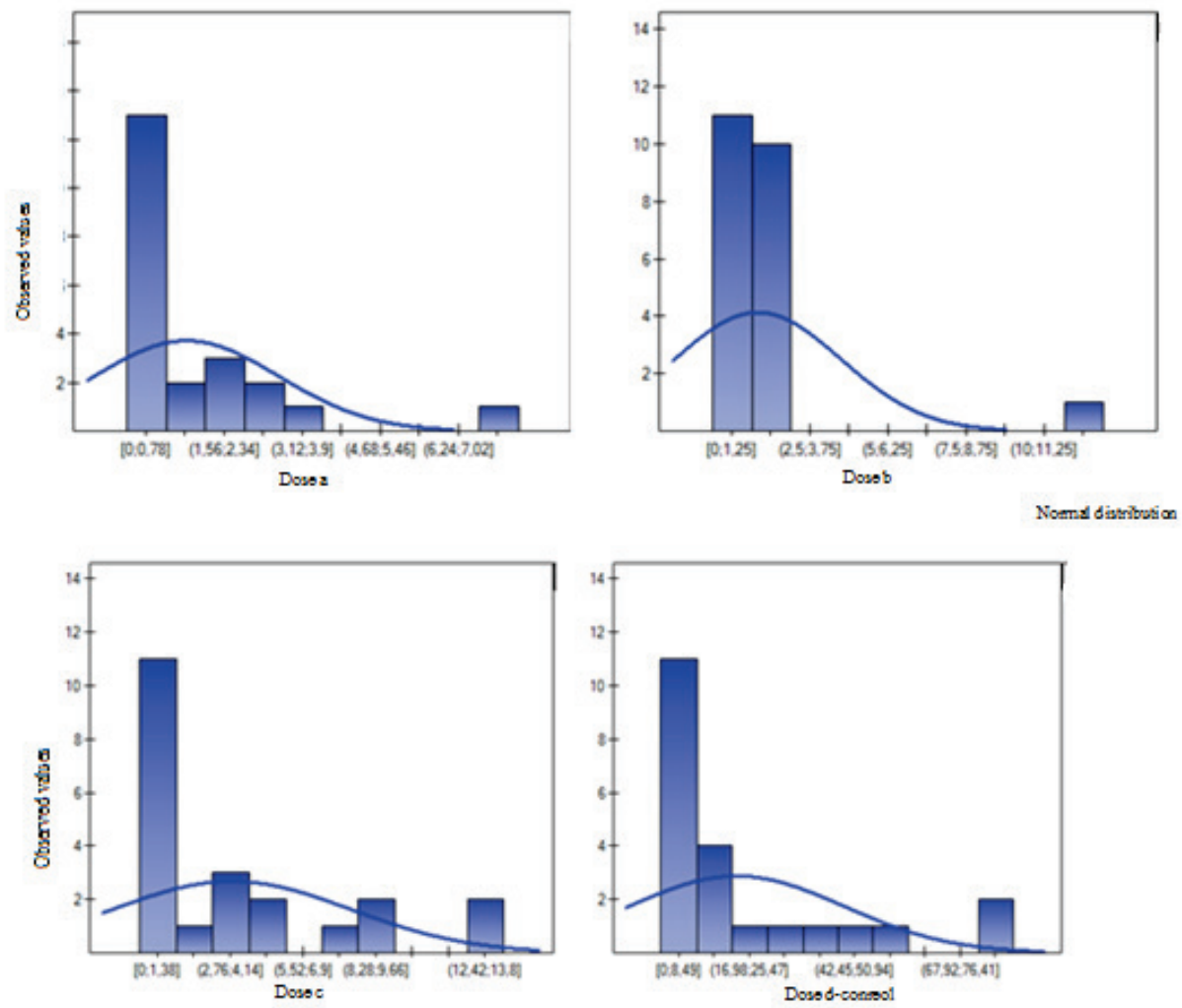

Figure. 2. Normal distribution test for individual doses of the preparation in relation to the number of infected fruiting bodies

Due to the fact that data distribution is not a normal distribution, the Spearman rank correlation non-parametric test was used for further statistical analysis.

Before analysis of the correlation between the size of the preparation doses and the number of infected fruiting bodies of cultivated mushrooms, Pearson's coefficient of linear correlation test was carried out. Figure 1 shows an example of the dependency between the applied dose $\mathrm{c}$ and control dose $\mathrm{d}$. Since the descriptive statistics obtained for all variants of this dependency fall within the range of $p=0.000001$, we cannot speak of linear correlation, because $\mathrm{p}<0.05$. 


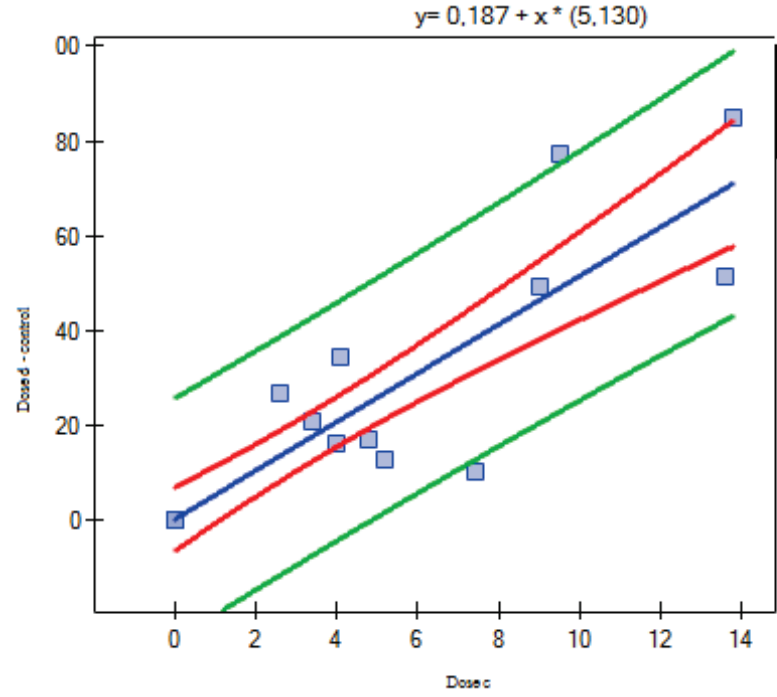

- (x,y)

- Linear

- Confidence interval 95\%

— Prediction interval 95\%

Figure 3. Linear correlation test for the variant where the number of infected fruiting bodies after the use of dose $c$ was compared to control dose d

Since distribution is not normal and there is no linear correlation, the non-parametric test of Spearman rank monotonic relationship was applied in the studied case. The results of the obtained analysis of the correlation of the preparation doses in relation to the number of infected fruiting bodies of cultivated mushrooms with the control dose are presented in Fig. 4,5 and 6.

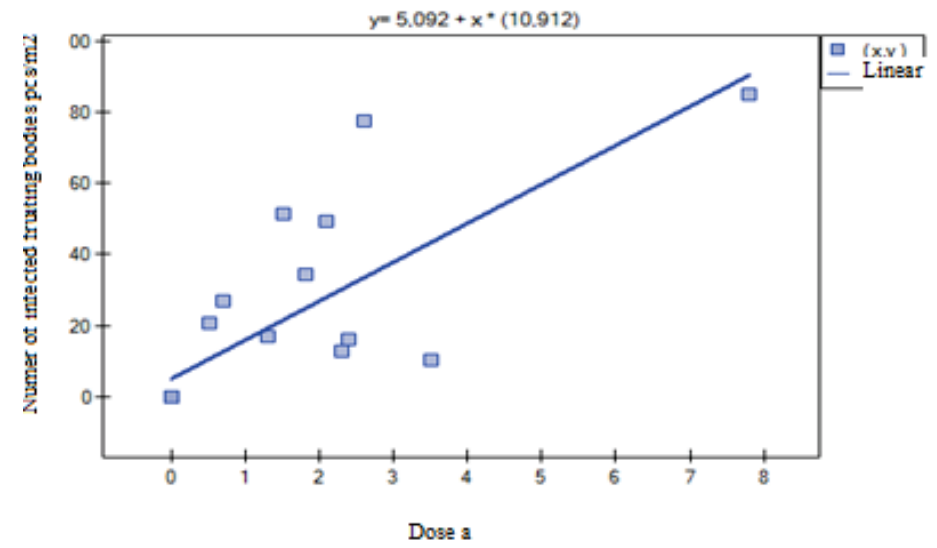

Figure 4. Correlation between dose $A$ and the number of infected fruiting bodies in relation to control dose D 


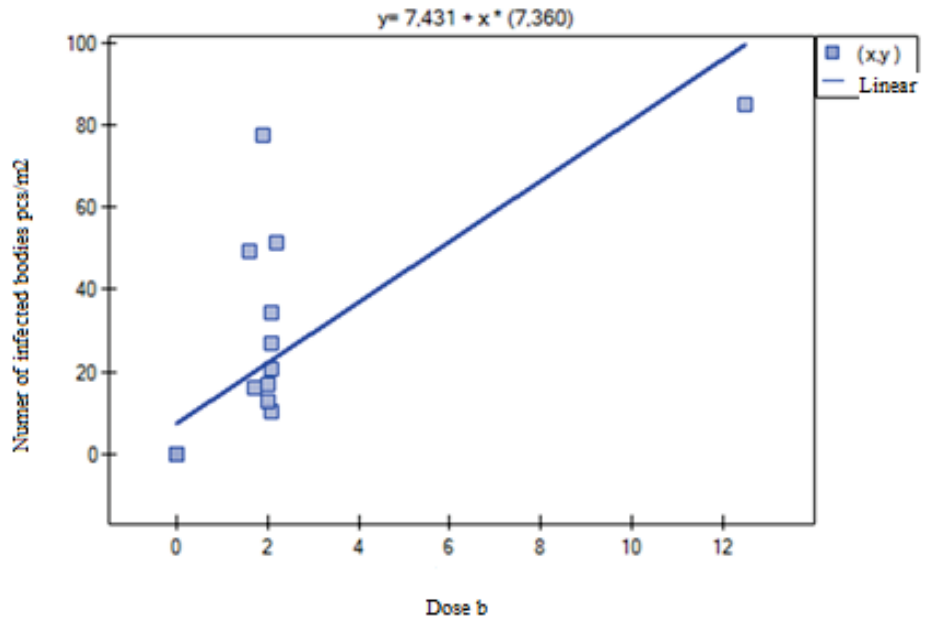

Figure 5. Correlation between dose B and the number of infected fruiting bodies in relation to control dose D

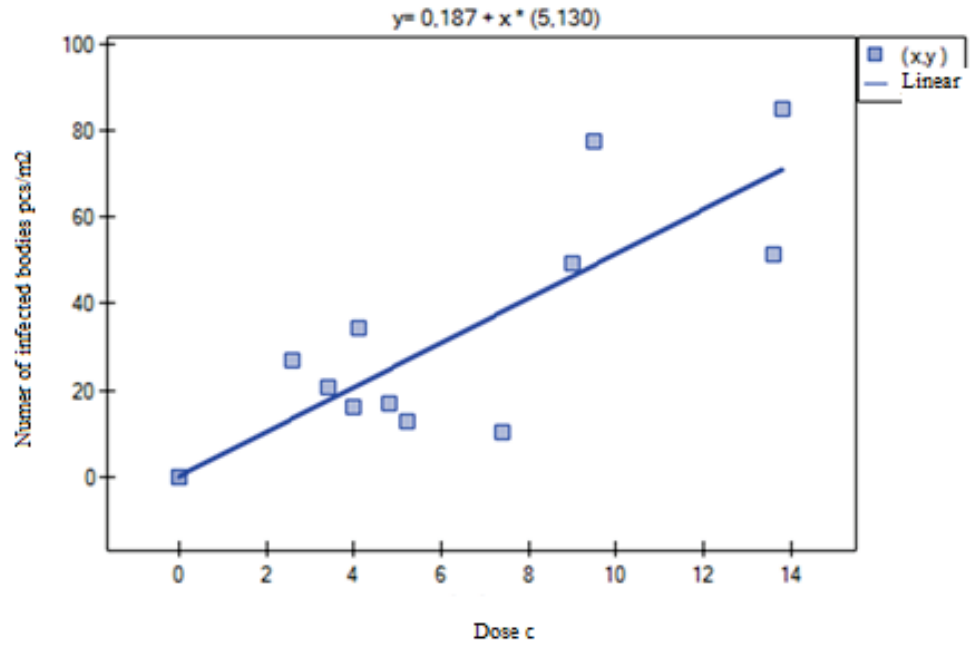

Figure 6. Correlation between dose $C$ and the number of infected fruiting bodies in relation to control dose $D$

Table 2 shows the $\mathrm{R}^{2}$ coefficients obtained for different variants. Figure 7 shows the number of infected fruiting bodies in correlation to the individual doses of the preparation containing beneficial microorganisms. 
Katarzyna Szwedziak, Ewa Polańczyk

Table 2.

$R^{2}$ coefficient for individual variants of Spearman's rank correlation

\begin{tabular}{lccc}
\hline Descriptive statistics & Dose A & Dose B & Dose C \\
\hline $\mathrm{R}^{2}$ & 0.87 & 0.89 & 0.93 \\
$\mathrm{r}_{\mathrm{s}}$ & 0.10 & 0.09 & 0.07 \\
\hline
\end{tabular}

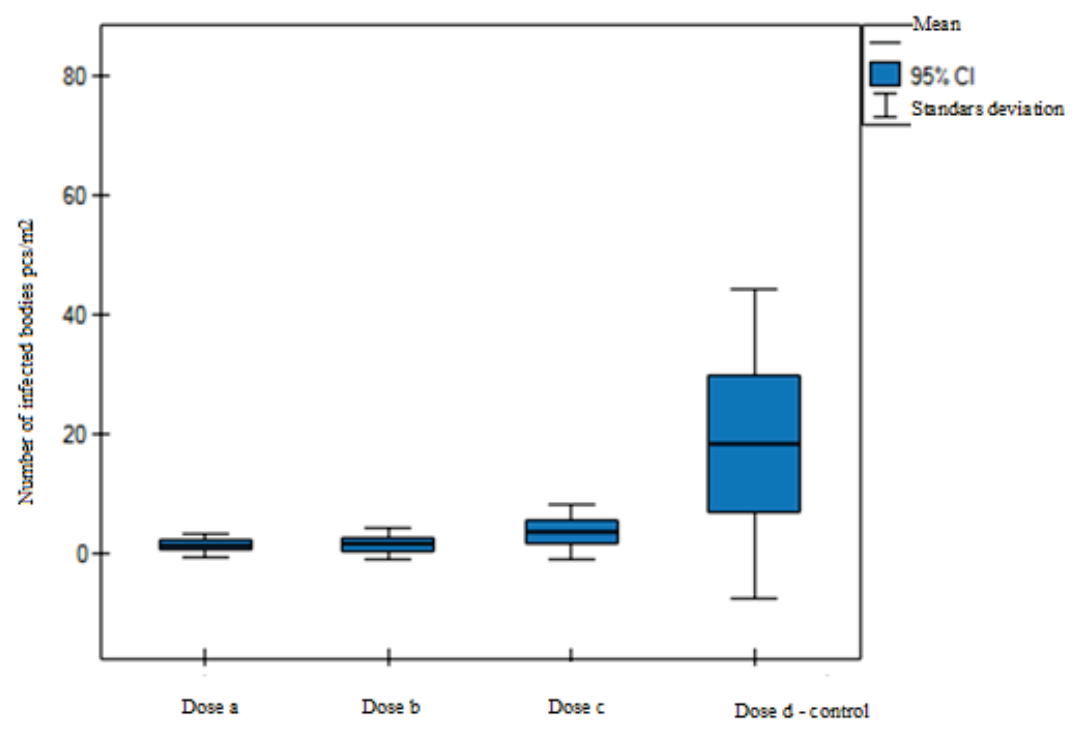

Figure 7. Correlation of the number of infected fruiting bodies to the individual doses of the preparation containing beneficial microorganisms (own source)

On the basis of the descriptive statistics obtained and by analysing the diagrams, it can be said that there is a completely positive monotonic relationship between the size of doses of the preparation containing beneficial microorganisms and the number of infected fruiting bodies of the cultivated common mushrooms. Together with the increase of the dose of the preparation containing beneficial microorganisms, the number of the infected fruiting bodies of the cultivated mushroom decreases. Using dose A we reduce the number of the infected fruiting bodies of cultivated mushrooms.

\section{Conclusions}

The use of preparations containing beneficial microorganisms has a significant impact on the number of infected fruiting bodies of cultivated common mushrooms. Based on the experiment described in this paper, it was found that the use of dose A with the concentration of $1.6 \%$ results in a reduction in the number of the infected fruiting bodies by $93 \%$ in comparison to traditional cultivation. The Spearman rank correlation test confirmed this conclusion. On the basis of the descriptive statistics obtained, a positive monotonic rela- 
Statistical modelling...

tionship between the size of doses of the preparation and the number of the infected fruiting bodies was confirmed. For dose A with the concentration of 1.6, the $\mathrm{r}_{\mathrm{s}}$ coefficient totalling 0.10 was recorded, and for the remaining doses the coefficient was 0.09 and 0.07 , respectively.

\section{References}

Adams, L.S., Phung, S., Wu, X., K,i L., Chen, S.S. (2008). White button mushroom (Agaricus Bisporus) exhibits antiproliferative and proapoptotic properties and inhibits prostate tumor growth in athymic mice. Nutrition and Cancer, 60(6), 744-756.

Beelman, R.B., Royse, D., Chikthimmah, N. (2003). Bioactive components in Agaricus Bisporus (J. LGE). (2010). Imbach of nutritional, medicinal, or biological importance. International Journal of Medicinal Mushrooms, 5, 11-19.

Clarke, J. (2010). Mushrooms: the new superfood. Twickenham,

Martyniuk, S. (2011). Skuteczne i nieskuteczne preparaty mikrobiologiczne stosowane w ochronie i uprawie roślin oraz rzetelne i nierzetelne metody ich oceny (Effective and ineffective microbiological preparations used in the protection and cultivation of plants, and reliable and unreliable methods of their evaluation). Postepy Mikrobiologii, 50(4), 321-328.

Mazur, E. (2004). Analiza ekonomiczna modelowego gospodarstwa pieczarkarskiego (Economic analysis of mushroom-growing plant), Master's thesis, Warsaw University of Life Sciences SGGW, Warsaw.

Szudyga, K. (2008). Dwanaście procent (Twelve per cent), Biuletyn Pieczarki, No. 2, 11-15.

Ślusarski, Cz., Uliński, Z., Szumigaj-Tarnowska, J. (2012). Ocena występowania chorób i stanu sanitarnego w polskich pieczarkarniach.(A survey of the sanitary conditions and the occurrence of infectious diseases on Polish mushroom farms). Progress in Plant Protection/Postepy w Ochronie Roślin, 52(4), 1052-1057.

Staniszewski, P. (2014). Użytkowanie grzybów leśnych-praktyka i problemy badawcze. Studia i Materiały CEPL w Rogowie, R.16.Zeszyt 39/2B, 143-152.

Tekiela, A. (2005). Grzyby patogeniczne w uprawie pieczarki dwuzarodnikowej Agaricus bisporus (Lange.) Imbach, Acta Agrobotanica, 58(2), 189-19.

Trajer, M., Dyngus M. (2013). Krajowa produkcja, spożycie oraz promocja owoców i warzyw. Biuletyn Informacyjny Agencji Rynku Rolnego, Zakład Ekonomiki Ogrodnictwa, Warszawa.

Wang, L., Hou, Y. (2011). Determination of trace elements in anti-influenza virus mushrooms. Biological trace element research, 143(3), 1799-1807.

Wojciechowska-Mazurek, M., Mania, M., Starska, K., Rebeniak, M., Karłowski, K. (2011). Pierwiastki szkodliwe dla zdrowia w grzybach jadalnych w Polsce. Bromatologia i Chemia Toksykologiczna, 44(2), 143-149. 
Katarzyna Szwedziak, Ewa Polańczyk

\section{OCENA STATYSTYCZNA WYSTECPOWANIA LICZBY \\ PORAŻONYCH OWOCNIKÓW PIECZARKI \\ W UPRAWIE ZINTEGROWANEJ Z PREPARATAMI ZAWIERAJĄCYMI POŻYTECZNE MIKROORGANIZMY}

Streszczenie. W związku z niska skutecznością lub wysokimi kosztami stosowania środków chemicznych $\mathrm{w}$ ochronie pieczarki producenci zmuszeni są do poszukiwania metod alternatywnych ochrony. Jedną z takich metod jest zastosowanie preparatów zawierających pożyteczne mikroorganizmy. W pracy dokonano oceny statystycznej tej metody ochrony pieczarki i określenia liczby występowania porażonych owocników.

Słowa kluczowe: pieczarka, porażone owocniki, ocena statystyczna, pożyteczne mikroorganzimy 